\title{
ANALISIS IMPLEMENTASI COORPORATE SOSIAL RESPONSIBILITY (CSR) BERDASARKAN PRINSIP GOOD COORPORATE GOVERNANCE DI PT. BIO NUSANTARA TEKNOLOGI
}

\author{
Oleh : \\ EVI LORITA \\ Dosen Prodi Administrasi Publik Fakultas Ilmu Sosial UNIVED Bengkulu
}

\begin{abstract}
This research aims to investigate the implementation and factors that impede the implementation of Corporate Social Responsibility (CSR) which is based on the principle of Good Corporate Governance Good Corporate Governance (GSG) in PT. Bio Nusantara Teknologi. This research uses a descriptive method of analysis with a qualitative approach and data collection performed by the method of instrumental case studies, documentary studies, and natural observation (observation depth). The results show that six areas of activity that the CSR programs have been implemented by PT. BNT to improve well being communities are Education, Social Affairs / Religion, Health, Infrastructure, Economic and Environmental Affairs. Second, funds budgeted in the implementation of CSR programs at the PT. BNT were fit with the intelligence of UUPM No.25 Tahun 2007 in the amount of 1-5\% of the company's profit after tax. Third, the social sector undertaken by PT.BNT to the CSR programs simply touch the community, where it is seen from the social program / religion that has been done, the areas of health and education.As for the program of environment and the economy has not been so touching peoples. Fourth, CSR applied by PT. BNT based GCG show that the implementation is not visible transparent principles, accountability, responsibility and fairness. Fifth, the existence of CSR programs in the form of community development that has been carried out by PT.BNT still lacks of impacts and benefits to improve the welfare of the local community, because of lack of fulfilling wishes of local communities, especially in the fields of economics, education and infrastructure development.And sixth, the implementation of CSR programs in the form of community development in the PT.BNT reap many obstacles and challenges, such as lack of budget funds and the scope and location of the village area around the company, so that distribution is not equitable relief.
\end{abstract}

Keywords: implementation analysis, corporate social responsibility, good corporate governance 


\section{PENDAHULUAN}

Peranan CSR
dipandang sebagai upaya untuk
mewujudkan good corporate
governance, good corporate
citizenship dan good business ethics
dari sebuah entitas bisnis, sehingga
perusahaan tidak cukup hanya
memikirkan kepentingan
shareholder (pemilik modal), tetapi
juga mempunyai orientasi untuk
memenuhi kepentingan seluruh
stakeholders (Raynard \& Forstater
dalam Mapisangka, 2009:55).

Di Indonesia regulasi mengenai CSR telah diatur oleh pemerintah sejak tahun 1994 dengan dikeluarkannya Keputusan Menteri Keuangan Republik Indonesia No. 316/KMK/016/1994 tentang Program Pembinaan Usaha Kecil dan Koperasi oleh Badan Usaha Milik Negara, yang kemudian dikukuhkan lagi dengan Keputusan Menteri Negara Badan Usaha Milik Negara No. Kep-236/MBU/2003 yang menetapkan bahwa setiap perusahaan diwajibkan menyisihkan laba setelah pajak sebesar $1 \%$ sampai dengan $5 \%$ (Pasal 4), untuk menjalankan CSR.

Akan tetapi, kewajiban melaksanakan CSR oleh pemerintah sekarang ini bukan hanya dibebankan pada BUMN saja. Melalui Undang-Undang No. 40 tahun 2007 pasal 74 tentang Perseroan Terbatas (UU PT) dan Undang-Undang No. 25 tahun 2007 pasal 15 (b) dan pasal 16 (d) tentang Penanaman Modal (UU PM), maka setiap perseroan atau penanam modal diwajibkan untuk melakukan sebuah upaya pelaksanaan tanggung jawab perusahaan yang telah dianggarkan dan diperhitungkan sebagai biaya
Perseroan. Kebijakan ini juga mengatur sanksi bagi perusahaan yang tidak menjalankan kewajiban tersebut.

CSR secara etimologis kerap diterjemahkan sebagai tanggung jawab sosial dan lingkungan perusahaan. Namun setelah tanggal 16 Agustus 2007, CSR di Indonesia telah di atur dalam Undang-Undang Nomor 40 tahun 2007 tentang Perseroan Terbatas yang mengantikan Undang-Undang Nomor 1 tahun 1995 tentang Perseroan Terbatas. CSR yang dikenal dalam Undang-Undang ini sebagaimana yang termuat dalam Pasal 1 ayat 1, 2, 3 yang berbunyi:

1. Perseroan yang menjalankan kegiatan usahanya di bidang dan/atau yang berkaitan dengan sumber daya alam wajib melaksanakan Tanggung Jawab Sosial dan Lingkungan.

2. Tanggung Jawab Sosial dan Lingkungan sebagaimana yang dimaksud dalam ayat (1) merupakan kewajiban perseroan yang dianggarkan dan diperhitungkan sebagai biaya perseroan yang pelaksanaannya dilakukan dengan memperhatikan kepatutan dan kewajaran.

3. Perseroan yang tidak melaksanakan kewajiban sebagaimana yang dimaksud dalam ayat (1) dikenai sanksi sesuai dengan ketentuan peraturan perundang-undangan.

4. Ketentuan lebih lanjut mengenai Tanggung Jawab Sosial dan Lingkungan diatur dengan Peraturan Pemerintah.

$$
\text { Perusahaan perkebunan }
$$

kelapa sawit dituntut untuk lebih 
berbuat nyata. Oleh karena itu, sudah saatnya perusahaan perkebunan kelapa sawit untuk menerapkan program CSR-nya dengan mengakomodasi tuntutan-tuntutan stakeholders demi pembangunan kelapa sawit berkelanjutan. Perusahaan perkebunan kelapa sawit perlu menunjukkan komitmennya untuk memperkuat hal-hal positif dan mengeliminir hal-hal negatif. Beberapa hal yang dapat menjadi bagian dari program CSR perusahaan kelapa sawit mulai saat ini di antaranya adalah:

1. Membantu peningkatan produktivitas perkebunan kelapa sawit rakyat di sekitar perusahaan,

2. Membantu perbaikan infrastruktur (jalan dan jembatan) di kebun produksi di wilayah perkebunan rakyat,

3. Membantu penyediaan teknologi melalui fasilitasi kegiatan penelitian dan pengembangan,

4. Memfasilitasi resolusi konflik sosial di wilayah-wilayah yang masih dilanda konflik,

5. Menerapkan analisis dampak lingkungan di wilayah perusahaan dan sekitarnya,

6. Mendorong implementasi partisipasi masyarakat secara efektif dalam perencanaan penggunaan/pemanfaatan lahan untuk mengantisipasi masalah yang mungkin terjadi antara perusahaan dan masyarakat sekitar serta banyak langka lainnya.

PT. BNT yang merupakan perusahaan pemproduksi CPO yang ada di Kabupaten Bengkulu Tengah, dalam memproduksi CPO perusahaan ini tidak terlepas dari persaingan perusahaan yang memproduksi barang sejenis. Keadaan itulah yang memaksa perusahaan dalam memproduksi CPO harus selalu memperhatikan kualitas/mutu, harga, waktu, dan tempat. Dari faktor-faktor tersebut, mutu mempunyai peranan penting didalam memberikan kepuasan dan menentukan pilihan konsumen.

Pengembangan perusahaan dari mulanya hanya berfokus pada perkebunan kemudian mengembangkan diri dengan membangun pabrik pengolahan $\mathrm{CPO}$ merupakan perkembangan yang sangat baik bagi perusahaan. Hal ini menunjukan eksistensi perusahaan kepada dunia luar semakin baik. Akan tetapi sejalan dengan hal tersebut, maka perusahaan juga harus memperhatikan hal-hal penting yang merupakan bagian dari keberlangsungan perusahaan. Dimana dalam pelaksanaan aktivitas perusahaan terdapat beberapa hal yang harus menjadi fokus perusahaan, seperti:

1. Memperhatikan dan mengendalikan keselamatan dan kesehatan tenaga kerja baik di pabrik maupun tenaga kerja di perkebunan,

2. Pengendalian sistem pembuangan limbah pabrik bagi kesehatan lingkungan sekitar perusahaan,

3. Menjaga hubungan sosial kepada pemerintah maupun kepada masyarakat sekitar areal perusahaan,

4. Meningkatkan taraf kesejahteraan karyawan dan tenaga kerja di perusahaan, 
5. Melakukan sistem pembebasan lahan masyarakat sekitar secara layak dan transparansi,

6. Melakukan hubungan baik kepada para pemasok dan kepada stakeholders lainnya.

Kegiatan tersebut di atas merupakan bentuk implementasi dari program CSR yang dilakukan oleh PT. BNT. Hal ini sejalan dengan visi perusahaan yaitu "Menjadi pusat keunggulan pengelolaan perusahaan agroindustri kelapa sawit dengan tata kelola perusahaan yang baik serta berwawasan lingkungan". Bentuk kepedulian PT. BNT pada lingkungan dan masyarakat ditangani oleh bagian Humas (Hubungan Masyarakat) yang berkoordinir langsung dengan pimpinan.

Program CSR di PT. BNT dilaksanakan secara berkelanjutan, konsekuen dan transparan. PT. BNT sudah lebih maju dalam melaksanakan Undang-Undang yang wajib dilaksanakan oleh perusahaan yang berkecimpung atau memanfaatkan sumber daya alam ini. Dengan kata lain, PT. BNT tidak hanya sekedar menjaga komitmen kepada masyarakat tapi juga patuh terhadap amanat Undang-Undang No. 40/2007. Dengan ini, program CSR yang dilakukan oleh PT. BNT tersebut ingin menerapkan konsep 3P, yakni profit, people dan planet sebagai filosofi dalam menjalankan usaha sekaligus untuk mewujudkan tata kelola perusahaan yang baik atau good corporate governance (GCG).

Berdasarkan latar belakang tersebut penulis tertarik melakukan penelitian terhadap Analisis Implementasi Corporate Social Responsibility (CSR) Berdasarkan Prinsip Good Corporate Governance
(GCG) Di PT. Bio Nusantara Teknologi. Adapn tujuan dari penelitian ini adalah mengetahui Implementasi Corporate Social Responsibility (CSR) Berdasarkan Prinsip Good Corporate Governance (GCG) Di PT. Bio Nusantara Teknologi.

\section{METODE PENELITIAN}

Dalam penelitian ini penulis menggunakan metodelogi dengan pendekatan kualitatif, yang memiliki karakteristik alami (natural setting) sebagai sumber data langsung, deskriptif, proses lebih diutamakan daripada hasil, analisis dalam penelitian kualitatif cenderung dilakukan secara analisa induktif dan makna merupakan hal yang esensial (Moleong, 2002:3).

Dalam penelitian ini peneliti menggunakan teknik pengumpulan data adalah wawancara, observasi dan dokumentasi. Analisis data menggunakan analisis data kualitatif, maka dalam analisis data selama di lapangan peneliti menggunakan model Spradley, yaitu teknik analisa data yang didisesuaikan dengan tahapan dalam penelitian

\section{HASIL PENELITIAN DAN PEMBAHASAN}

\section{Implementasi CSR Berdasarkan Prinsip GCG Di PT. Bio Nusantara Teknologi}

Sesuai dengan Visi PT. Bio Nusantara Teknologi, "Menjadi Perusahaan dengan kapasitas bisnis terintegrasi yang unggul di dalam industri sawit nasional". Dimana 
salah satu misi perusahaan dalam mewujudkan program CSR adalah "Mewujudkan kepedulian pada lingkungan dan komunitas melalui program kemasyarakatan yang efektif'. Visi dan misi inilah yang diwujudkan menjadi berbagai program peningkatan kesejahteraan, peningkatan kelestarian alam dan lingkungan sekitar serta pemberdayaan masyarakat.

Dari hasil wawancara diketahui bahwa pada dasarnya program-program sosial dan lingkungan telah dilakukan oleh perusahaan. Program-program tersebut bersifat bantuan sosial untuk masyarakat sekitar perusahaan baik dalam bidang pendidikan, ekonomi, agama, kesehatan dan lingkungan. Semua kegiatan tersebut yang kemudian dimasukan ke dalam agenda pelaksanaan program CSR PT. BNT.

\section{Komitmen PT. Bio Nusantara Teknologi Terhadap Tanggung Jawab Sosial, Ekonomi Dan Lingkungan \\ Tanggung jawab sosial} perusahaan secara eksternal ditujukan kepada masyarakat sekitar perusahaan. Pelaksanaan CSR eksternal ini mempunyai tujuan untuk menjalin hubungan baik terhadap masyarakat sekitar dengan asas timbal balik yang saling menguntungkan.

Bantuan-bantuan dari PT. BNT yang disebutkan masyarakat sangat beragam, mulai pembangunan mesjid, bantuan hewan kurban pada hari raya idul adha, bantuan perlengkapan sekolah bagi siswasiswi yang tidak mampu, pemberian beasiswa bagi siswa-siswi yang tidak mampu dan berprestasi, pemeriksaan kesehatan dan pengobatan gratis bagi sebagian masyarakat. Dari pernyataan masyarakat, bantuan tersebut masih berorientasi jangka pendek karena lebih bersifat insidentil atau menunggu momentum/hari raya tertentu.

Untuk lebih jelasnya mengenai bantuan-bantuan yang telah diberikan oleh PT. BNT kepada masyarakat, berikut penulis tuangkan hasil wawancara dengan responden tentang bantuan-bantuan dari berbagai bidang, seperti berikut:

Komitmen Dan Kepatuhan PT. Bio Nusantara Teknologi Dalam Melaksanakan Prinsip-Prinsip GCG

Implementasi CSR PT. BNT dalam upaya pengembangan masyarakat dapat dilihat dari kegiatan-kegiatan yang telah PT. BNT laksanakan dalam beberapa tahun ini. PT. BNT telah melaksanakan berbagai kegiatan diberbagai bidang yang telah mencakup dalam ruang lingkup program pengembangan masyarakat. Community relation, dalam kategori ini, program cenderung mengarah pada bentuk-bentuk kedermawanan (charity) perusahaan. Dari hubungan ini, dapat dirancang pengembangan hubungan yang lebih mendalam dan terkait dengan bagaimana mengetahui kebutuhan-kebutuhan dan masalah-masalah yang ada di masyarakat lokal sehingga perusahaan dapat menerapkan program selanjutnya.

Dari keterangan mengenai program-program kegiatan CSR yang dilakukan oleh PT. BNT, 
berikut penulis uraikan berdasarkan prinsip-prinsip GCG, yaitu:

\section{Prinsip Transparansi}

(Keterbukaan Informasi)

Dalam mewujudkan prinsip ini perusahaan dituntut untuk menyediakan informasi yang cukup, akurat, tepat waktu kepada segenap stakeholdersnya. Pemenuhan akan prinsip ini diharapkan bahwa setiap hal yang berkaitan dengan pelaksanaan CSR oleh perusahaan dapat diketahui oleh semua orang. Baik pihak manajemen perusahaan maupun masyarakat. Akan tetapi dalam pelaksanaanya tidak demikian, informasi mengenai CSR ini masih sangat terbatas baik bagi karyawan maupun bagi masyarakat setempat, dimana informasi ini hanya ditujukan kepada pihak berkepentingan saja, seperti owner (pimpinan perusahaan dan media).

\section{Prinsip Accountability}

\section{(Akuntabilitas)}

Kejelasan fungsi, struktur, system dan pertanggungjawaban elemen perusahaan merupakan penerapan dari prinsip accountability ini. Apabila prinsip ini diterapkan secara efektif, maka akan ada kejelasan akan fungsi, hak, kewajiban dan wewenang serta tanggungjawab antara pemegang saham, dewan komisaris dan dewan direksi. Dalam pelaksanaannya, pihak manajemen hanya menunjuk orang-orang tertentu saja khususnya di departemen HRD untuk melaksanakan program CSR. Akan tetapi hal tersebut belum ditunjang dengan system dan struktur yang baku, sehingga nampak seperti kegiatan tersebut kurang terkoordinasi.

\section{Prinsip Responsibility (Pertanggung Jawaban).}

Bentuk pertanggung jawaban perusahaan ialah kepatuhan perusahaan terhadap peraturan yang berlaku, diantaranya: masalah pajak, hubungan industrial, kesehatan dan keselamatan kerja, perlindungan lingkungan hidup memelihara lingkungan bisnis yang kondusif bersama masyarakat.

\section{Prinsip Independency}

\section{(Kemandirian)}

Prinsip ini mensyaratkan agar perusahaan dikelola secara professional tanpa ada benturan kepentingan dan tanpa tekanan atau intervensi dari pihak manapun yang tidak sesuai dengan peraturanperaturan yang berlaku.

\section{Prinsip Fairness (Kesetaraan} dan Kewajaran)

Prinsip ini menuntut adanya perlakuan yang adil dalam memenuhi hak stakeholders sesuai dengan perundangan yang berlaku. Dari pandangan GCG, berdasarkan prinsip keadilan ini pada dasarnya masayarakat sekitar PT. BNT masih merasakan adanya ketidakadilan dalam berbagai bidang.

Berdasarkan hasil wawancara diketahui bahwa prinsip keadilan ini belum optimal dilakukan oleh manajemen PT. BNT. Rasa ketidakadilan yang dirasakan oleh masyarakat pada saat ini menjadi salah satu faktor yang dirasakan oleh masyarakat setempat.

\section{Tingkat Kepuasan Masyarakat Terhadap Implementasi CSR}

Minimnya pengaruh program CSR bagi masyarakat lokal tersebut disebabkan pertama, komunitas lokal umumnya adalah mereka yang 
kurang memiliki akses langsung terhadap keberadaan program CSR. Kedua, sebagian besar program CSR selama ini lebih banyak bersifat bantuan sosial, sedangkan masyarakat setempat menginginkan adanya bantuan dari perusahaan yang bersifat bantuan modal usaha.

Dari hasil wawancara penulis dengan informan menunjukan bahwa tingkat kepuasan masyarakat sekitar PT. BNT terhadap program-program bantuan yang telah diberikan oleh perusahaan masih belum memuaskan harapan masyarakat sekitar. Pada umumnya masyarakat lebih mengharapkan adanya bantuan langsung yang lebih menyentuh keinginan dan kebutuhan masyarakat, seperti bantuan modal usaha.

\section{Faktor-Faktor Penghambat Dalam Implementasi CSR Keterbatasan Dana}

Hal ini merupakan masalah utama bagi perusahaan. Dimana untuk melaksanakan program CSR yang benar-benar dapat menyentuh seluruh lapisan masyarakat tentunya membutuhkan dana yang cukup besar. Akan tetapi dana tersebut harus melalui proses anggaran tahunan berdasarkan perhitungan hasil laba rugi perusahaan tahun sebelumnya. Walaupun pada dasarnya ketentuan dana yang dikeluarkan oleh perusahaan sudah sesuai dengan ketentuan UUPT yaitu sebesar $1-5 \%$ dari laba perusahaan setelah pajak, akan tetapi untuk menjangkau semua masyarakat di lingkungan perusahaan membutuhkan anggaran yang sangat besar. Untuk diketahui bahwa anggaran dana dalam pelaksanaan
CSR meliputi segala aspek dalam pelaksanaan, mulai dari dana honor petugas, dana akomodasi, konsumsi, bahan-bahan perlengkapan, dan lain sebagainya.

\section{Jarak Lokasi}

Masalah yang kedua ini merupakan faktor penghambat yang cukup serius bagi perusahaan dalam melaksanakan program CSR. Kendala utama dalam pelaksanaan CSR setelah dana adalah jarak lokasi masyarakat dari lokasi perusahaan. Luasnya cakupan wilayah dan menyebarnya populasi masyarakat di perusahaan PT. BNT menjadi faktor yang harus dipertimbangkan oleh pihak perusahaan. Keadaan inilah yang menyebabkan alokasi pelaksanaan dari kegiatan-kegiatan CSR perusahaan menjadi terhambat. Jarak lokasi dan keadaan medan yang cukup rumit juga merupakan faktor yang akan memperbesar anggaran dana dalam pelaksanaan kegiatan CSR sehingga perusahaan harus melakukan berbagai analisa dan pertimbangan sebelum melaksanakan suatu kegiatan.

\section{PENUTUP}

\section{Kesimpulan}

Berdasarkan hasil penelitian dan pembahasan dalam bab sebelumnya, maka penulis menyimpulkan bahwa dalam pelaksanaannya bidang sosial yang dilaksanakan oleh PT. BNT terhadap program CSR cukup menyentuh masyarakat, dimana hal tersebut dilihat dari program bidang sosial/agama yang dilakukan, bidang kesehatan dan bidang pendidikan. 
Sedangkan untuk program bidang lingkungan hidup dan ekonomi belum begitu menyentuh masyarakat. CSR yang diterapkan PT. BNT berdasar prinsip GCG menunjukan bahwa pada pelaksanaannya belum terlihat prinsip transparency, accountability, responsibility dan fairness.

\section{Saran}

Berdasarkan kesimpulan di atas, maka penulis menyarankan: Perlu ada reformulasi kebijakan dan realokasi anggaran CSR. Serta Pihak manajemen perusahaan seharusnya menentukan program-program kegiatan CSR berdasarkan pada kebutuhan masyarakat stempat dengan melakukan survey secara langsung dan memberikan dukungan dana secara penuh terhadap pelaksanaan CSR yang ada.

\section{DAFTAR PUSTAKA}

Ambadar Chairi. 2009. Landasan Filsafat dan Metode Penelitian Kualitatif. Semarang, Fakultas Ekonomi Undip

Gurvy Kavei dalam Teguh. 2006. Tanggung Jawab Sosial Harus Dilakukan, Makalah pada seminar "Corporate Social Responsibility": Integrating Social Acpect into The Business: Yogyajarta

Rudito, Bambang dan Melia Femiola. 2007. Etika Bisnis Dan Tanggung Jawab Social Perusahaan Di Indonesia. Bandung, Rekayasa Sains
Kurniawan. 2013. Analisis Implementasi Corporate Social Responsibility Pada PT. Newmont Nusatenggara Dalam Peningkatan Kesejahteraan Komunitas Lokal. Makasar, Universitas Hasanuddin

Yuriko, Putra Widenta. 2011. Jurnal: Analisis Implementasi Corporate Social Responsibility PT. Indosat Tbk. Tahun 2007-2011 Berdasarkan Global Reporting Initiative.

Sugiyono. 2007. Metode Penelitian Administrasi. Bandung, Alfabeta

Undang-Undang Republik Indonesia Nomor 3 Tahun 1982 Tentang Wajib Daftar Perusahaan

Undang-Undang Republik Indonesia Nomor 25 Tahun 2007 Tantang Penanaman Modal

Undang-Undang Republik Indonesia Nomor 40 Tahun 2007 Tentang Perseroan Terbatas.

Aldi Primanand, Nuri Amila, dkk.2014. Artikel: Pengaturan CSR dalam Hukum Perusahaan. (http://edubadrus3.blogspot.c om/2013/03/pengaturan-csrdalam-hukumperusahaan.html) 
CSR Indonesia. 2007.

(http://www.csrindonesia.co $\underline{\mathrm{m} / \text { data/articles/20070912093 }}$ 106-a.pdf/diakses pada 17 Maret 2014)

Daniri, Achmad. 2008. Standarisasi Tanggung Jawab Perusahaan. indonesia)

Rahmawati, Dini. 2012. Sampling dan Informan Dalam Penelitian Kualitatif. http://www.scribd.com/doc/9 2793272/Sampling-DanInforman-Dalam -PenelitianKualitatif

Inayah Sabir, Nurul. 2014. Skripsi. Analisis Implementasi Corporate Social Responsibility (CSR) PT. Semen Tonasa Dalam Upaya Pengembangan Masyarakat Sekitar.

Kaihatu. 2006. Good Corporate Governance Dan Penerapannya Di Indonesia. (http://puslit2.petra.ac.id/ejou rnal/index.php/man/article/vie wFile/16505/16497/diakses pada 18 Maret 2014)

Nandasaputri. 2013. Pengantar Hukum Bisnis, Pengertian Perusahaan.

http://nandasaputri189.wordp ress.com/2013/10/18/pengant ar-hukum-bisnis-pengertianperusahaan/
Nurkhin, Ahmad. 2010. Corporate Governance Dan Profitabilitas Pengaruhnya Terhadap Pengungkapan CSR.

(www.journal.unnes.ac.id/ind ex/php/jda/articles/download/ 1927/2045/diakses pada 18 Maret 2014)

Putera Widenta Yuriko. 2011. Jurnal: Analisis Implementasi Corporate Social Responsibility PT. Indosat Tbk. Tahun 2007-2011 Berdasarkan Global Reporting Initiative.

Raditta. 2012. Regulasi CSR Di Indonesia. (http://raditta.wordpress.com/ 2012/04/24/regulasi-csr-diindonesia/diakses 02 juni 2014)

Rahmatullah. 2014. Masalah Pengelolaan Program Corporate Social Responsibility (CSR) Pada Sektor Pertambangan. (http://www.rahmatullah.net/ 2010/05/masalahpengelolaan-programcorporate.html)

Rosita. 2010. Corporate Social Responsibility. (http://rosita.staff.uns.ac.id/20 10/07/23/corporate-socialresponsibility/diakses pada 17 Maret 2014) 


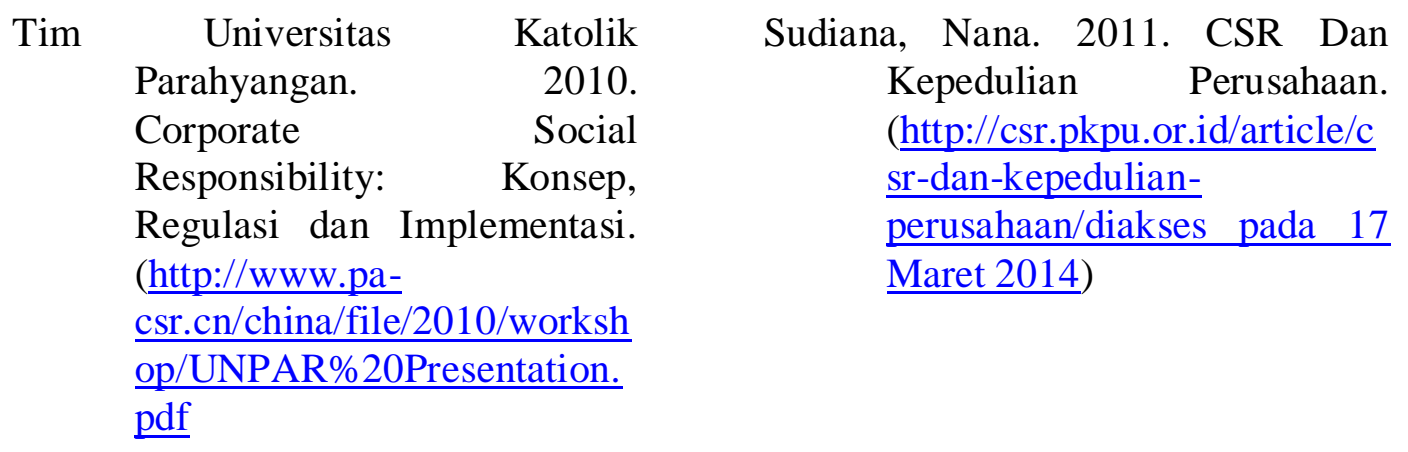

